\title{
Pneumologia
}

\section{Cardiopulmonary exercise testing in thoracic surgery}

\author{
Irina Pele ${ }^{1, *}$, Florin-Dumitru Mihălțan²,3 \\ 1 "Marius Nasta" Institute of pneumophtisiology, Lung Function Tests Department, Bucharest, Romania \\ 2 "Marius Nasta" Institute of pneumophtisiology, Pneumology 3, Bucharest, Romania \\ Abstract \\ 3 "Carol Davila" Univesity of Medicine and Pharmacy, Bucharest, Romania \\ English: \\ The assessment of functional capacity is a significant part of the preoperative evaluation of patients proposed for both thoracic \\ and abdominal surgery. The cardiopulmonary exercise test (CPET) is the most comprehensive exercise test currently used. It \\ provides an objective assessment of the patient's training level and an individualised risk profile for complications and guides the \\ perioperative care. This article provides a brief description of the roles of CPET in thoracic surgery. Guidelines recommend it for \\ perioperative assessments because of its prognostic value, its utility in the postoperative period and in pulmonary rehabilitation \\ programmes.
}

Keywords

cardiopulmonary exercise test $\bullet$ functional capacity $\bullet$ thoracic surgery

\section{Testarea cardio-pulmonară la efort în chirurgia toracică}

Rezumat

Romanian:

Testarea toleranței la efort este o parte importantă a evaluării preoperatorii a pacienților propuși pentru intervenții chirurgicale toracice și abdominale. Cel mai complex test de efort utilizat la ora actuală este testul de efort cardio-pulmonar (TECP), care oferă o evaluare obiectivă a nivelului de antrenament la efort al pacientului și un profil individualizat al riscului de complicații, ghidând îngrijirea perioperatorie. Lucrarea de față descrie rolul testării cardio-pulmonare la efort în chirurgia toracică, de la indicațiile în evaluarea perioperatorie până la valoarea prognostică și utilitatea sa în construcția programelor de reabilitare respiratorie.

Cuvinte-cheie

test cardio-pulmonar de efort • toleranță la efort • chirurgie toracică

\section{Introduction}

A simple dictionary definition of exercise tolerance is "the level of physical effort an individual can perform before exhaustion" (1). Therefore, exercise intolerance is the inability to perform a physical exercise at the intensity level and for the expected time, according to age, sex, body weight and estimated physical fitness. Currently, the promotion of regular exercise is an area of public health interest (2,3). Several clinical studies highlighted the benefits of maintaining a good physical condition in the prevention or after the development of chronic cardiovascular (heart failure, coronary artery disease and hypertension) (4-6), pulmonary (Chronic Obstructive Pulmonary Disease COPD) (7), renal diseases (8) and cancer (9).

"Corresponding author: Irina Pele, "Marius Nasta" Institute of Pneumophthisiology, Bucharest, Șoseaua Viilor 90, 050159, Bucharest, Romania E-mail: irinapele1@yahoo.com 
Most of the patients undergoing thoracic surgery suffer from lung cancer (10) and its associated comorbidities. They often have a multifactorial limitation of their exercise capacity due to ventilatory, cardiovascular, musculoskeletal or psychological disorders $(9,11)$. This is one of the reasons why international guidelines state that functional capacity assessments are essential for preoperative evaluation $(9,10)$. The peak/maximal exercise capacity evaluation through cardiopulmonary exercise test (CPET) can help in assessing perioperative risks, influences the type of intervention performed and helps to improve organ dysfunctions in the preoperative period $(12,13)$. Although several fields and laboratory exercise tests are currently accepted in assessing exercise performance, the CPET represents the "gold standard" $(14,15)$.

This article aims to provide a summary overview of CPET. We will address, in particular, its roles in the preoperative evaluation, prognosis of morbidity and mortality, postoperative assessment and pulmonary rehabilitation of thoracic surgery patients.

\section{CPET overview}

CPET is a dynamic test that evaluates the respiratory, cardiac, circulatory, metabolic and muscular functions, under standardised and controlled physiological conditions $(14,15)$. The body's integrated response to exercise is evaluated through direct measurement of respiratory gas exchange and pulmonary ventilation, using the "breath-by-breath" method, which involves the use of a sealed oronasal mask. The electrocardiogram, blood pressure, heart rate and arterial oxygen saturation (pulse oximetry) are recorded as well (14-17; Figure 1).

The CPET methodology requires specialised equipment for measuring breathing and cardiovascular parameters (an exercise testing station), including a cycle ergometer or treadmill, trained personnel and working protocols $(14,15)$. Nowadays, the test is still not available in many of the world's medical centres due to the high cost and the training required. In the perioperative evaluation, the cycle ergometer is usually preferred, with the recommendation to perform a maximum incremental or ramp test with an average exercise duration of $8-12 \min (16,18)$. The test stops when the patient reaches the limit of exercise tolerance, that is, at the point where his/ her symptoms no longer allow him/her to continue cycling, despite the technician's encouragement $(16,18)$. The test aims to provide the most helpful information related to the functional status of the patient (14-16). Similar to other CPET workouts, it includes four stages: rest, warm-up (unloaded pedalling), continuous incremental/ramp exercise and recovery (15).

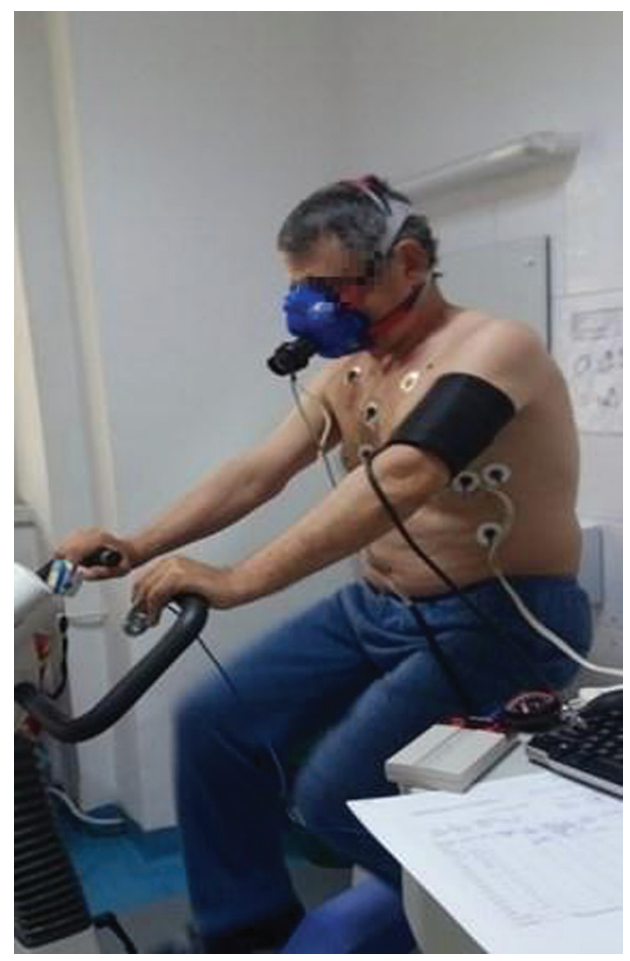

Figure 1. Cardiopulmonary exercise test on the cycle ergometer.

A synthesis on the utility of the data provided by the CPET in surgical patients, as it was underlined, in several systematic reviews on this subject, is presented below:

- CPET objectively appreciates the patient's physical fitness and identifies the cause of exercise intolerance; when the exercise capacity is decreased, it can identify the limiting factors (respiratory, cardiac, neuromuscular, etc.) $(15,17)$;

- CPET can guide the preoperative management decision: to cancel or to postpone surgery, to guide the choice of surgical procedure (limited or extended surgical resection) or oncology treatment (19-21);

- CPET can facilitate the identification of underlying comorbidities and thus provides the possibility to optimise patient's treatment (e.g. heart failure, ischaemic cardiac disease and pulmonary hypertension) (15-17, 20-22);

- CPET estimates the risk of adverse events (morbidity or mortality) of the patient $(19,20,22,23)$;

- CPET guides anaesthesia procedures and immediate postoperative care level needed, thereby reducing postoperative morbidity $(20,22)$;

- CPET assesses the patient's functional capacity after surgery, providing information on the required mode and length of recovery after lung resections (19); 
- CPET assists with tailoring an individualised pulmonary rehabilitation programme, in the pre and/or postoperative period $(19,20,22)$;

- CPET allows assessing the effects of oncologic therapy (neoadjuvant chemo- or chemo-radiotherapy) in lung cancer (20).

\section{CPET in the preoperative evaluation}

As part of the preoperative assessment of thoracic surgery patients, the need for the functional capacity evaluation is highly evident in the medical literature and primarily concerns patients with lung cancer (23-27). Thus, over the period 2003 to 2013, experts from American and European Respiratory and Thoracic Surgeons Societies published a series of evidence-based guidelines for the diagnosis and stratification of high-risk patients with lung cancer (23-27).

From our point of view, the method may also be useful in patients who need surgical treatment due to other pulmonary diseases-benign tumours, localised lung infections (abscess, aspergilloma and tuberculoma) and infected bronchiectasis. Thus, physicians will be able to classify the patients with increased risk of complications and assess the impact of the intervention on lung function and quality of life. The decision for surgery is all the more complex as patients get older and have associated comorbidities, and secondary mortality is still a burden of health $(20,22,28,29)$.

The subject's cardiovascular status and lung function dictate the need for preoperative CPET. After completing the test, the physicians can decide whether the patient is "fit for surgery" (20) or not. Over the years, guideline recommendations regarding patient selection varied but were all based on the following parameters: the forced expiratory volume in one second (FEV1), diffusing capacity of the lung for carbon monoxide (DLCO) and their predicted postoperative (PPO) values (Figure 2). The 3rd edition of the American College of Chest Physician (ACCP) guideline, the newest published guideline on this subject (2013), recommends performing preoperative CPET in patients with lung cancer with ppoFEV1 and/or ppoDLCO below $30 \%$ predicted (28).

Predicted postoperative lung function (ppoFEV1 and ppoDLCO) may be calculated by estimating the amount of unobstructed lung tissue that would be resected (25-28). The methods used may include anatomic formulas involving bronchopulmonary segments to be removed, ventilation and/ or perfusion scan, quantitative CT scan and oxygen-enhanced MRI (25). The anatomic method is often applied to estimate lung function after lobectomy, whereas the radionuclide perfusion scan is preferred for pneumonectomy (25-28).

\section{The prognostic value of CPET}

Studies regarding the utility of the CPET in identifying patients with high risk of postoperative complications are numerous,

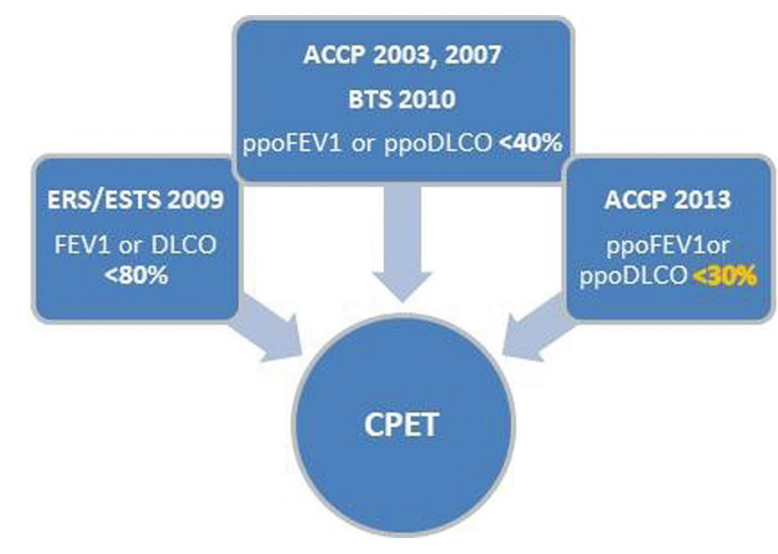

Figure 2. The place of CPET in guidelines recommendation according to FEV1, DLCO and their PPO values. ACCP, American College of Chest Physician; BTS, British Thoracic Society; CPET, cardiopulmonary exercise test; DLCO, diffusing capacity of the lung for carbon monoxide; ERS/ESTS, European Respiratory Society/European Society of Thoracic Surgeons; FEV1, forced expiratory volume in 1 second; PPO, predicted postoperative.

and many of them dedicated to non-cardiothoracic surgery (23). Some variables of the CPET have been proven useful as significant predictors of morbidity and mortality: peak oxygen consumption ( $\mathrm{VO}_{2}$ peak), anaerobic threshold (AT) and ventilatory equivalent for carbon dioxide $\left(\mathrm{VE} / \mathrm{VCO}_{2}\right.$ slope $)$ $(19,20,22,23)$.

$\mathrm{VO}_{2}$ peak and AT are the measures of subject's exercise capacity and are expressed in millilitres of $\mathrm{O}_{2}$ uptake per minute $(\mathrm{ml} / \mathrm{min})$, millilitres of $\mathrm{O}_{2}$ uptake per minute and per kilogramme of body weight $(\mathrm{ml} / \mathrm{min} / \mathrm{kg})$ or as a percentage of their predicted values (22). The gas exchange efficiency is assessed by the ventilatory equivalents, such as VE/ $\mathrm{VCO}_{2}$. Some examples of identified cut-off points of risk and associated outcomes for these three CPET variables are presented in Table 1.

\section{Peak oxygen uptake $\left(\mathrm{VO}_{2}\right.$ peak)}

$\mathrm{VO}_{2}$ peak is the highest value of oxygen uptake measured during CPET, at the end of the incremental exercise phase, and it is the most used parameter describing the subject's functional capacity in surgery candidates (14-16). When the oxygen uptake reaches a physiological end-point, maximum $\mathrm{VO}_{2}\left(\mathrm{VO}_{2} \mathrm{max}\right)$ is the term used (16). $\mathrm{VO}_{2}$ peak $\left(\mathrm{VO}_{2} \max \right)$ is associated with postoperative morbidity and mortality, with independent predictive value for major surgical interventions $(30-32)$. A disadvantage of $\mathrm{VO}_{2}$ peak is that it can be influenced by the patient's motivation, early cessation of the exercise test leading to an incorrect exclusion from a potentially curative surgical treatment (16).

Over the years, there were controversies about the best thresholds which separate the lower risk from the intermediary/ high risk for complications after lung resections. For this 
Table 1. Parameters of the CPET with threshold values and their postoperative outcome

\begin{tabular}{|c|c|c|c|}
\hline & Reference & Risk threshold & Outcome \\
\hline \multirow[t]{7}{*}{$\mathrm{VO}_{2}$ peak or $\mathrm{VO}_{2} \max$} & Bechard et al. $1987(n=50)(30)$ & $<10 \mathrm{ml} / \mathrm{kg} / \mathrm{min}$ & $\begin{array}{l}29 \% \text { mortality and } 43 \% \text { morbidity }\left(10.7 \% \text { morbidity if } 10<\mathrm{VO}_{2} \text { max }\right. \\
\left.<20 \mathrm{ml} / \mathrm{kg} / \mathrm{min} ; \text { no mortality } / \text { morbidity if } \mathrm{VO}_{2}>20 \mathrm{ml} / \mathrm{kg} / \mathrm{min}\right)\end{array}$ \\
\hline & Brunelli et al. $2009(n=204)(31)$ & $<12 \mathrm{ml} / \mathrm{kg} / \mathrm{min}$ & $\begin{array}{l}13 \% \text { mortality and } 33 \% \text { morbidity (no mortality, } 3.5 \% \text { morbidity if } \mathrm{VO}_{2} \\
>20 \mathrm{ml} / \mathrm{kg} / \mathrm{min} \text { ) }\end{array}$ \\
\hline & Smith et al. $1984(n=22)(32)$ & $<15 \mathrm{ml} / \mathrm{kg} / \mathrm{min}$ & $100 \%$ morbidity \\
\hline & Byram et al. $2007(n=55)(33)$ & & $39 \%$ morbidity (no morbidity if $\mathrm{VO}_{2} \geq 15 \mathrm{ml} / \mathrm{kg} / \mathrm{min}$ ) \\
\hline & \multirow[t]{2}{*}{ Bolliger et al. $1995(n=80)(35)$} & $<60 \%$ & $\begin{array}{l}85.5 \% \text { probability of complications after resection involving more than } \\
\text { one lobe }\end{array}$ \\
\hline & & $<43 \%$ & $90 \%$ probability of serious complications \\
\hline & Larsen et al. $1997(n=97)(36)$ & $<50 \%$ & $60 \%$ sensitivity of mortality risk \\
\hline AT & Guazzi et al. 2016 (39) & $<11 \mathrm{ml} / \mathrm{kg} / \mathrm{min}$ & High risk of complications (proposed prognostic marker) \\
\hline \multirow[t]{3}{*}{$\mathrm{VE} / \mathrm{VCO}_{2}$ slope } & Torchio et al. $2010(n=145)(40)$ & $\geq 34$ & $\begin{array}{l}5.5 \% \text { of patients predicted not to survive after surgery }(98 \% \text { of patients } \\
\left.\text { predicted to survive if VE/ } / \mathrm{VCO}_{2}<34\right) \\
\text { The only independent mortality predictor }\end{array}$ \\
\hline & Brunelli et al. $2012(n=225)(41)$ & $>35$ & $\begin{array}{l}\text { High risk of respiratory complications ( } 22 \% \text { vs. } 7.6 \% \text { ) and mortality } \\
(7.2 \% \text { vs. } 0.6 \%) \text {; comparison with patients with } \mathrm{VE} / \mathrm{VO}_{2} \leq 35\end{array}$ \\
\hline & Miyazaki et al. $2018(n=974)(44)$ & $>40$ & $\begin{array}{l}\text { 90-day mortality: } 16 \% \text { vs. } 5 \% \\
\text { 2-year mortality: no difference (comparison with patients with } \\
\text { VE/ } / \mathrm{VCO}_{2} \leq 40 \text { ) }\end{array}$ \\
\hline
\end{tabular}

AT, anaerobic threshold; CPET, cardiopulmonary exercise test; $\mathrm{VE} / \mathrm{VCO}_{2}$ slope, the ventilatory equivalent for $\mathrm{CO} 2$ slope; $\mathrm{VO}{ }_{2}$ peak/max, peak/maximum oxygen uptake; n, number of patients.

purpose, most cohort studies use absolute values indexed to body weight instead of the percentage of the predicted value. Such cut-off points of $\mathrm{VO}_{2}$ for higher risk of postoperative adverse events were 10,12 and $15 \mathrm{ml} / \mathrm{kg} / \mathrm{min}$, respectively (30-34).

On the other hand, some studies have shown a better discriminatory ability of oxygen consumption expressed as a percentage of the predicted value. The mentioned cut-off points of risk are in descending order from $60 \%$ to $40 \%$ predicted (34-36). However, using only absolute values can underestimate the real physical fitness of patients in clinical practice, with particular implications for certain categories of persons such as the elderly, the obese and subjects of short height (5).

It is now certain that patients with values $>20 \mathrm{ml} / \mathrm{kg} / \mathrm{min}$ (or $75 \%$ predicted) can undergo major interventions such as pneumonectomy. While in patients with values $<10 \mathrm{ml} / \mathrm{kg} / \mathrm{min}$ (or $35 \%$ predicted), oncological or palliative treatments are preferable (28).

\section{Anaerobic threshold}

AT or the lactate threshold is a measure of the submaximal exercise capacity. It is the oxygen consumption $\left(\mathrm{VO}_{2}\right)$ achieved almost entirely under aerobic conditions when the lactic acid serum level starts to increase (reflecting anaerobic glycolysis) with metabolic acidosis (14-16,22). Unlike $\mathrm{VO}_{2}$ peak, it is a non-volitional variable and reflects an increase in the contribution of anaerobic metabolism to aerobic one in the presence of restricted oxygen supply (22). It is a predictor of postoperative morbidity and mortality for major elective surgery (especially intra-abdominal surgical procedures) $(22,23,37)$ and cardiovascular diseases (myocardial ischaemia and heart failure) (38), with a threshold value for high risk ranging from 9 to $11 \mathrm{ml} / \mathrm{kg} / \mathrm{min}(22,23,37,38)$. The absolute value of $\mathrm{VO}_{2}$ at AT indexed to bodyweight seems to be the best predictor of postoperative complications $(22,23)$. The literature is poor in evidence-based data about AT in thoracic surgery.

Guazzi et al. (39) proposed a CPET-based algorithm for presurgical risk assessment, which includes $\mathrm{VO}_{2}$ at AT. An AT $<11 \mathrm{ml} / \mathrm{kg} / \mathrm{min}$ is considered to be a prognostic marker of high risk for complications, especially when it is associated with a low $\mathrm{VO}_{2}$ peak and high $\mathrm{VE} / \mathrm{VCO}_{2}$ values (39).

\section{The ventilatory equivalent for $\mathrm{CO}_{2}$}

The ratio of the minute ventilation to $\mathrm{CO}_{2}$ output is the expression of gas exchange efficiency, whose prognostic value has started to emerge in recent years (40-44). Similar to the AT, VE/ $\mathrm{VCO}_{2}$ is a variable measured at the submaximal workload $(16,19,22)$.

Increased values of ventilatory equivalents were described in several diseases, such as heart failure (45), pulmonary hypertension (46) or pulmonary fibrosis (47), emphasising a poor prognosis. The parameter was also analysed in clinical studies of surgery candidates, including thoracic surgery patients, and it was suggested that it could be even a better predictor of respiratory morbidity and mortality compared with $\mathrm{VO}_{2} \max (40,41,43)$. Again, the threshold risk values used in the triage of patients are different between studies. These values vary from 34 to 40 (40-44). Moreover, current studies 
develop the idea that $\mathrm{VE} / \mathrm{VCO}_{2}$ could be a significant predictor of short- and long-term survival $(42,44)$.

All these differences between studies could be explained by the progress of health systems, with improved patient screening, surgical and care technique or a variety in the number and/or origin of the population samples. However, the optimal predicted parameters and their risk delimitation threshold in thoracic surgery remain controversial at present, requiring more extensive studies $(20,22)$.

\section{CPET in postoperative assessment}

Although CPET is not among the routinely performed tests in the postoperative period, there are a few studies that analysed the effect of lung resection on exercise capacity $(19,48)$.

$\mathrm{Ha}$ et al. described nine studies in their meta-analysis on patients with lung cancer performing CPET (19). Those studies showed the dynamics of lung function after partial or total lung resections at various intervals 3, 6 and 12 months. The majority of patients who underwent lobectomy had a recovery of exercise tolerance within 3 month after surgery (19). As expected, due to a broader limitation of the functional reserve, patients who underwent pneumonectomies have a slower recovery or do not recover at all even after $>6$ months from the surgery (49).

The influence of pulmonary resections on the results of lung function tests and exercise capacity is noteworthy. Longitudinal studies measuring respiratory parameters after lung resections showed discrepancies between the pulmonary function recovery and the recovery of exercise capacity $(50,51)$. Caution is mandatory during preoperative assessments in order not to underestimate the functional status by limiting evaluations only to lung function test evidence $(50,51)$.

\section{CPET in pulmonary rehabilitation}

Physical training induces an adaptive response of the whole body, and it is the best way to increase effort capacity in anticipation of future physiological stress $(12,18,20)$. During surgery, both the physiological challenge of the intervention itself and the anaesthesia induce stress (20).
Reports from the studies in recent years suggest that based on CPET parameters, the physician can prescribe the physical training necessary in pulmonary rehabilitation programmes and can also asses their effectiveness $(19,52)$. A feasible and effective pulmonary rehabilitation programme can increase the AT and $\mathrm{VO}_{2}$ peak, minimising the negative impact of surgical stress on cardiopulmonary and metabolic functions $(12,20)$. Systematic reviews described the effect of preoperative physical training in reducing the number of postoperative complications, the length of hospital stays and in improving the quality of life in patients with lung cancer $(53,54)$.

Currently, for patients undergoing thoracic surgery, short-term high-intensity interval training (HIIT) regimes can be an option $(20,55,56)$. Symptom limited-CPET is performed first, with the determination of $\mathrm{VO}_{2}$ peak and peak work rate (WRpeak)the highest exercise level maintained for about $20 \mathrm{~s}$ (56). The patients must repeat the test after 3 or 4 weeks of training. A significant change $(>10 \%)$ in $\mathrm{VO}_{2}$ peak defines a positive response to rehabilitation (55).

The design of a HIIT programme is shown in Figure 3 by using adapted data previously published $(55,56)$. Participants usually exercise on a cycle ergometer 2-3 times a week under the supervision of a physiotherapist $(55,56)$. The work rate is adjusted to obtain near maximal heart rates towards the end of the sprint interval (56).

The HIIT programme individualised by measured CPET variables resulted in a meaningful improvement in cardiorespiratory fitness compared with usual care $(20,22,55,56)$.

In the postoperative period, a pulmonary rehabilitation programme can also improve the quality of life, minimising symptoms like breathlessness. Kim et al. (57) demonstrated the benefits of a 6-month systemic pulmonary rehabilitation programme after lung resection surgery in their study. The patient exercised at least three times a day for $20 \mathrm{~min}$. The sessions focussed on chest expansion exercises, segmental breathing, respiratory muscle training and breathing control training (57). Training exercises helped to enhance

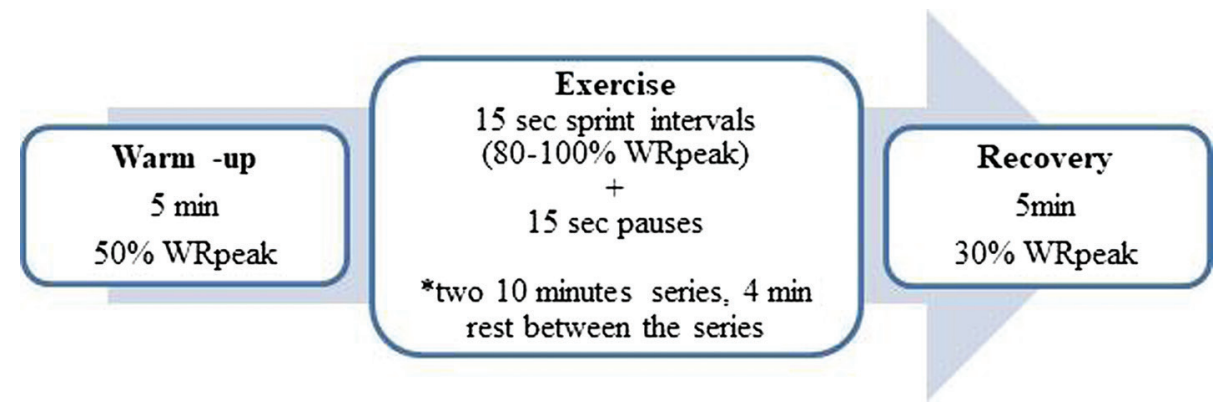

Figure 3. Design of a HIIT programme (adapted from published data) $(55,56)$. HIIT, high-intensity interval training; WRpeak, peak work rate. 
performance status and prevent the postoperative decline of lung function parameters (57).

Supervised long-term postoperative training and patients' educational and counselling programmes regarding physical activity are needed to maintain a better functional and clinical outcome $(56,57)$.

\section{Conclusion}

Information provided by the CPET is complex. It can be used in thoracic surgery to assess the potential risk of morbidity and mortality, define particular patient profiles and make subsequent therapeutic decisions, including choosing a pulmonary rehabilitation programme.

\section{Declaration of interest}

The authors have no conflict of interest to declare.

\section{References}

1. Medical Dictionary for the Health Professions and Nursing. Farlex; 2012 [cited 8 dec. 2019]. Available from: https://medicaldictionary.thefreedictionary.com/exercise+tolerance.

2. WHO Guidelines Approved by the Guidelines Review Committee. Global recommendations on physical activity for health 2010. Geneva: World Health Organization Copyright (c) World Health Organization; 2010.

3. Salis RE. Exercise is medicine and physicians need to prescribe it! British Journal of Sports Medicine. 2009;43: 3-4.

4. Nayor M, Vasan RS. Preventing heart failure: the role of physical activity. Current Opinion in Cardiology. 2015;30(5): 543-550.

5. Winzer EB, Woitek F, Linke A. Physical activity in the prevention and treatment of coronary artery disease. Journal of the American Heart Association. 2018;7(4): e00725.

6. Hegde SM, Solomon SD. Influence of physical activity on hypertension and cardiac structure and function. Current Hypertension Reports.2015;17(10): 77.

7. Spruit MA, Pitta F, McAuley E, ZuWallack RL, Nici L. Pulmonary rehabilitation and physical activity in patients with chronic obstructive pulmonary disease. American Journal of Respiratory and Critical Care Medicine. 2015;192: 924-933.

8. Qui Z, Zheng K, Zhang H, Feng J, Wang L, Zhou H. Physical exercise and patients with chronic renal failure: a meta-analysis. BioMed Research International. 2017;2017: 7191826.

9. Bade BC, Thomas DD, Scott JB, Silvestri GA. Increasing physical activity and exercise in lung cancer. Reviewing safety, benefits, and application. Journal of Thoracic Oncology. 2015;10: 861-871.
10. Jin $\mathrm{K}, \mathrm{Hu} \mathrm{Q}, \mathrm{Xu}$ J, Wu C, Hsin MK, Zirafa CC, et al. The 100 most cited articles on thoracic surgery management of lung cancer. Journal of Thoracic Disease. 2019;11(11): 4886-4903.

11. Spruit MA, Singh SJ, Garvey C, ZuWallack R, Nici L, Rochester $\mathrm{C}$, et al. An official American thoracic society/European respiratory society statement: key concepts and advances in pulmonary rehabilitation. American Journal of Respiratory and Critical Care Medicine. 2013;188: e13-e64.

12. Carli F, Minnella EM. Preoperative functional assessment and optimization in surgical patient: changing the paradigm. Minerva Anestesiol. 2017;83: 214-218.

13. Glance LG, Osler TM, Neuman MD. Redesigning surgical decision making for high-risk patients. The New England Journal of Medicine. 2014;370: 1379-1381.

14. Wasserman K, Hansen JE, Sue DY, Stringer WW, Sietsema KE, Sun XG, et al. Principles of exercise testing and interpretation. 5th ed. Philadelphia, PA: Lippincott Williams \& Wilkins; 2012.

15. American Thoracic Society, American College of Chest Physicians. ATS/ACCP statement on cardiopulmonary exercise testing. American Journal of Respiratory and Critical Care Medicine. 2003;167: 211-277.

16. Levett DZH, Jack S, Swart M, Carlisle J, Wilson J, Snowden C et al. Perioperative cardiopulmonary exercise testing (CPET): consensus clinical guidelines on indications, organizations, conduct, and physiological interpretation. British Journal of Anaesthesia. 2018;120: 419-421.

17. Palange P, Ward SA, Carlsen KH, Casaburi R, Gallagher CG, Gosselink R, et al. Recommendations on the use of exercise testing in clinical practice. European Respiratory Journal. 2007;29: 185-209.

18. Levett DZ, Grocott MPW. Cardiopulmonary exercise testing, prehabilitation, and Enhanced Recovery After Surgery (ERAS). Canadian Journal of Anesthesia. 2015;62: 131-142.

19. Ha D, Mazzone PJ, Ries AL, Malhotra A, Fuster M. The utility of exercise testing in patients with lung cancer. Journal of Thoracic Oncology. 2016;11(9): 1397-1410.

20. Richardson K, Levett DZH, Jack S, Grocott MPW. Fit for surgery? Perspectives on preoperative exercise testing and training. British Journal of Anaesthesia. 2017;119(S1): i34-i43.

21. Huddart S, Young El, Smith RL, Holt PJ, Prabhu PK. Preoperative cardiopulmonary exercise testing in England - a National Survey. Perioperative Medicine. 2013;2: 4.

22. Older PO, Levett DZH. Cardiopulmonary exercise testing and surgery. Annals of the American Thoracic Society. 2017;14(1): S74-S83.

23. Moran J, Wilson F, Guinan E, McCormick P, Hussey J, Moriarty $\mathrm{J}$. Role of cardiopulmonary exercise testing as a risk-assessment method in patients undergoing intra-abdominal surgery: a systematic review. British Journal of Anaesthesia. 2016;116: 177-191.

24. Beckles MA, Spiro SG, Colice GL, Rudd RM. The physiologic evaluation of patients with lung cancer being considered for resectional surgery. Chest. 2003;123: 105S-114S 
25. Colice GL, Shafazand S, Griffin JP, Keenan R, Bolliger CT. Physiologic evaluation of the patient with lung cancer being considered for resectional surgery. ACCP evidence-based clinical practice guidelines (2nd edition). Chest. 2007;132: 161S-177S.

26. Brunelli A, Charloux A, Bolliger CT, Rocco G, Sculier JP, Varela $G$, et al. ERS/ESTS clinical guidelines on fitness for radical therapy in lung cancer patients (surgery and chemo-radiotherapy). European Respiratory Journal. 2009;34: 17-41.

27. Lim E, Baldwin D, Beckles M, Duffy J, Entwisle J, Faivre-Finn C, et al. Guidelines on the radical management of patients with lung cancer. Thorax. 2010;65(Suppl. 3): iii1-iii27.

28. Brunelli A, Kim, AW, Berger KI, Addrizzo-Haris DJ. Physiologic evaluation of the patient with lung cancer being considered for resectional surgery. Diagnosis and management of lung cancer, 3rd ed: American College of Chest Physicians evidence-based clinical practice guidelines. Chest. 2013;143: e166S-e190S.

29. Pearse RM. Moreno RP, Bauer P, Pelosi P, Metnitz P, Speis C, et al. Mortality after surgery in Europe: a 7-day cohort study. Lancet. 2012;380: 1059-1065.

30. Bechard D, Wetstein L. Assessment of exercise oxygen consumption as preoperative criterion for lung resection. The Annals of Thoracic Surgery. 1987;44: 344-349.

31. Brunelli A, Belardinelli R, Refai M, Salati M, Socci L, Pompili C, et al. Peak oxygen consumption during cardiopulmonary exercise test improves risk stratifications in candidates to major lung resection. Chest. 2009;135: 1260-1267.

32. Smith TP, Kinasewitz GT, Tucker WY. Exercise capacity as a predictor of post-thoracotomy morbidity. The American Review of Respiratory Disease. 1984;129: 730-734.

33. Bayram AS, Candan T, Gebitekin C. Preoperative maximal exercise oxygen consumption test predicts postoperative pulmonary morbidity following major lung resection. Respirology. 2007;12: 505-510.

34. Mazzone PJ. Preoperative evaluation of the lung cancer resection candidate. Expert Review of Respiratory Medicine. 2010;4(1): 97-113.

35. Bolliger CT, Jordan P, Solèr M, Stulz P, Grädel E, Skarvan K et al. Exercise capacity as a predictor of postoperative complications in lung resection candidates. American Journal of Respiratory and Critical Care Medicine. 1995;151: 1472-1480.

36. Larsen KR, Svendsen UG, Milman N, Brenøe J, Petersen $\mathrm{BN}$. Exercise testing in the preoperative evaluation of patients with bronchogenic carcinoma. European Respiratory Journal. 1997;10: 1559-1565.

37. Snowden CP, Prentis JM, Anderson HL, Roberts DR, Randles $\mathrm{R}$, Renton $\mathrm{M}$, et al. Submaximal exercise testing predicts complications and hospital length of stay in patients undergoing major elective surgery. Annals of Surgery. 2010;251(3): 535-541.
38. Older P, Hall A. Clinical review: how to identify high-risk surgical patients. Critical Care. 2004;8: 369-372.

39. Guazzi M, Arena R, Halle M, Piepoli MF, Myers J, Lavie CJ. 2016 focused update: clinical recommendations for cardiopulmonary exercise testing data assessment in specific patient populations. Circulation. 2016;133: e694-e711.

40. Torchio R, Guglielmo M, Giardino R, Ardissone F, Ciacco C, Gulotta $\mathrm{C}$, et al. Exercise ventilatory inefficiency and mortality in patients with chronic obstructive pulmonary disease undergoing surgery for non-small-cell- lung cancer. European Journal of Cardio-Thoracic Surgery. 2010;38: 14-19.

41. Brunelli A, Belardinelli R, Pompili $C$, Xiumé F, Refai $M$, Salati $\mathrm{M}$, et al. Minute ventilation-to-carbon dioxide output $\left(\mathrm{VE} / \mathrm{VCO}_{2}\right)$ slope is the strongest predictor of respiratory complications and death after pulmonary resection. The Annals of Thoracic Surgery. 2012;93: 1802-1806.

42. Shafiek H, Valera JL, Togores B, Torecillia JA, Sauleda J, Cosio BG. Risk of postoperative complications in chronic obstructive lung diseases patients considered fit for lung cancer surgery: beyond oxygen consumption. European Journal of Cardio-Thoracic Surgery. 2016;50: 772-779.

43. Brunelli A. Ventilatory efficiency slope: an additional prognosticator after lung cancer surgery. European Journal of CardioThoracic Surgery. 2016;50: 780-781.

44. Miyazaki T, Callister MEJ, Franks K, Dinesh P, Nagayasu T, Brunelli A. Minute ventilation-to-carbon dioxide slope is associated with postoperative survival after anatomical lung resection. Lung Cancer. 2018;125: 218-222.

45. Shen Y, Zhang X, Ma W, Song H, Gong Z, Wang Q. VE/ $\mathrm{VCO}_{2}$ slope and its prognostic value in patients with chronic heart failure. Experimental and Therapeutic Medicine. 2015;9: 1407-1412.

46. Weatherald W, Farina S, Bruno N, Laveneziana P. Cardiopulmonary testing in pulmonary hypertension. Annals of the American Thoracic Society. 2017;14(1): S84-S92.

47. Triandafillidou C, Manali E, Lyberopoulos P, Kolilekas L, Kagouridis K, Gyftopoulos S, et al. The role of cardiopulmonary test in IPF prognosis. Pulmonary Medicine. 2013;ID 514817: 1-9.

48. Vaduc N. Physiology and clinical applications of cardiopulmonary exercise testing in lung cancer surgery. Thoracic Surgery Clinics. 2013;23: 233-245.

49. Nezu K, Kushibe K, Tojo T, Takahama M, Kitamura S. Recovery and limitation of exercise capacity after lung resection for lung cancer. Chest. 1998;113: 1511-1516.

50. Bolliger CT, Jordan P, Solèr M, Stulz P, Tamm M, Wyser Ch. et al. Pulmonary function and exercise capacity after lung resection. European Respiratory Journal. 1996;9: 415-421.

51. Win T, Groves AM, Ritchie AJ, Wells FC, Cafferty FC, Laroche $\mathrm{CM}$. The effect of lung resection on pulmonary function and exercise capacity in lung cancer. Respiratory Care. 2007;52(6): 720-726. 
52. Gao K, Yu P, Su J, He C, Liu L, Zhou Y, et al. Cardiopulmonary exercise testing screening and pre-operative pulmonary rehabilitation reduce postoperative complications and improve fasttrack recovery after lung cancer surgery: a study for 342 cases. Thoracic Cancer. 2015;6: 443-449.

53. Cavalheri V, Granger C. Preoperative exercise training for patients with non-small cell lung cancer. The Database of Systematic Reviews. 2017;6: CD012020.

54. Steffens D, Beckencamp PR, Hancock M, Solomon M, Young J. Preoperative exercise halves the postoperative complications rate in patients with lung cancer: a systematic review of the effect of exercise on complications, length of stay and quality of life in patients with lung cancer. British Journal of Sports Medicine. 2018;0: 1-9.
55. Licker M, Karenovics W, Diaper J, Frésard I, Triponez F, Ellenberger $\mathrm{C}$, et al. Short-term preoperative high-intensity interval training in patients awaiting lung cancer surgery: a randomized controlled trial. Journal of Thoracic Oncology. 2015;12(2): 323-333.

56. Karenovics W, Licker M, Ellenberger C, Christodoulou M, Diaper J, Bhatia C, et al. Short-term preoperative exercise therapy does not improve long-term outcome after lung cancer surgery: a randomized controlled study. European Journal of Cardio-Thoracic Surgery. 2017;52: 47-54.

57. Kim SK, Ahn Yh, Yoon JA, Shin MJ, Chang JH, Cho JS, et al. Efficacy of systemic postoperative pulmonary rehabilitation after lung resection surgery. Annals of Rehabilitation Medicine. 2015;39(3): 366-373. 